\title{
KARAKTERISTIK PERJANJIAN JUAL BELI MEDIUM TERM NOTES
}

\author{
Rosi Nani Putridewi \\ rosi.putridewi@gmail.com
}

Universitas Airlangga

\begin{abstract}
Capital Market is a part of financial market, besides money market which has essential role for national development, and specifically become funding alternative for small-medium business. Securities in Indonesia have been developing since 1980 after economic deregulation in financial field. This regulation brings some changes in Indonesia's financial market development, in terms of securities as a result of financial market development. Capital market instrument can be divided into bonds and stocks/equities. In this research, the writer focuses the research on capital market instruments in the form of Medium Term Notes (MTN). Unlike bonds, there are no regulations that have been regulated until now about Medium Term Notes. So that in this research, the focus is to discuss legal issues, namely the legal relationship of the parties in the Medium Term Notes sale and purchase agreement and the form of legal protection for investors holding Medium Term Notes. This research uses normative research method because this research tries to review legal norms, examining all constitutions and regulations which related to views and doctrines in laws. And the writer's main objective in this research is was to analyze the legal construction of the Medium Term Notes sale and purchase agreement and analyze the form of legal protection against buyers of Medium Term Notes. From this research, it is expected to contribute ideas in the field of law, especially in capital market legal disciplines and used to prevent and resolve legal problems that will arise in connection with the Medium Term Notes. Hopefully this journal can bring benefits, adding broader insight to readers.
\end{abstract}

Key Words: capital market, Medium Term Notes, Bonds.

\begin{abstract}
Abstrak
Surat berharga di Indonesia berkembang mulai tahun 1980 setelah adanya deregulasi ekonomi dalam bidang keuangan. Aturan ini membawa perubahan kepada berkembangnya pasar keuangan di Indonesia dimana surat berharga merupakan salah satu bentuk pengembangan pasar keuangan. Instrumen pasar modal dapat dibedakan atas surat berharga yang bersifat utang (bonds atau obligasi) yang merupakan bukti pengakuan utang dari perusahaan dan surat berharga yang bersifat pemilikan (equity atau saham) yang merupakan bukti penyertaan modal dalam perusahaan. Dalam penelitian ini, penyusun memfokuskan penelitian pada instrumen pasar modal berupa Medium Term Notes (MTN). Berbeda dengan Obligasi, untuk instrumen MTN sampai dengan saat ini masih belum ada pengaturannya. Sehingga dalam penelitian ini, memfokuskan untuk membahas permasalahan hukum yaitu hubungan hukum para pihak dalam perjanjian jual beli MTN dan bentuk perlindungan hukum terhadap Investor pemegang MTN.
\end{abstract}


Penelitian ini menggunakan metode penelitian normatif dikarenakan penelitian ini mencoba untuk mengkaji norma hukum yang menelaah semua Undang-undang dan regulasi yang bersangkut paut dan beranjak dari pandangan-pandangan dan doktrin-doktrin yang berkembang dalam ilmu hukum. Sasaran penyusun dalam penelitian ini adalah untuk menganalisis konstruksi hukum perjanjian jual beli Medium Term Notes dan menganalisis bentuk perlindungan hukum terhadap pembeli Medium Term Notes. Dari Penelitian ini diharapkan dapat menyumbangkan pemikiran di bidang ilmu hukum khususnya dalam disiplin ilmu hukum pasar modal dan digunakan untuk mencegah serta menyelesaikan permasalahan hukum yang akan timbul berkaitan dengan Medium Term Notes. Semoga penelitian ini dapat menjadi bacaan yang bermanfaat dan menambah wawasan bagi pembacanya.

Kata Kunci: Pasar modal, Medium Term Notes, Obligasi.

\section{A. PENDAHULUAN}

\section{Latar Belakang}

Pasar modal merupakan salah satu bagian dari pasar keuangan (financial market), disamping pasar uang (money market) ${ }^{1}$ yang sangat penting peranannya bagi pembangunan nasional pada umumnya, khususnya bagi pengembangan dunia usaha sebagai salah satu alternatif sumber pendanaan eksternal oleh perusahaan. Pasar modal memberikan peluang kepada masyarakat dan dunia usaha untuk melakukan investasi baik investasi jangka pendek, menengah maupun jangka panjang. Dalam Undang-Undang Nomor 8 Tahun 1995 Tentang Pasar Modal (selanjutnya disebut dengan Undang-Undang Pasar Modal), Pasar Modal didefinisikan sebagai kegiatan yang bersangkutan dengan Penawaran Umum dan perdagangan Efek, Perusahaan Publik yang berkaitan dengan Efek yang diterbitkannya, serta lembaga dan profesi yang berkaitan dengan Efek. ${ }^{2}$ Perkembangan pasar modal di Indonesia sendiri membawa dampak yang positif terhadap perekonomian Indonesia dimana pasar modal memiliki peranan yang sangat penting dalam suatu Negara, antara lain: ${ }^{3}$

a. Sebagai fasilitas melakukan interaksi antara pembeli dengan penjual, untuk menentukan harga saham atau surat berharga yang diperjualbelikan;

${ }^{1}$ Pasar Uang adalah bagian dari sistem keuangan yang bersangkutan dengan kegiatan perdagangan, pinjam-meminjam, atau pendanaan berjangka pendek sampai dengan 1 (satu) tahun dalam mata uang Rupiah dan valuta asing, yang berperan dalam transmisi kebijakan moneter, pencapaian stabilitas sistem keuangan dan kelancaran sistem pembayaran. (Peraturan Bank Indonesia Nomor 18/11/PBI/2016 tentang Pasar Uang, sebagaimana diundangkan dalam Lembaran Negara Republik Indonesia Tahun 2016 Nomor 148 dan Tambahan Lembaran Negara Republik Indonesia Nomor 5909).

${ }^{2}$ Efek adalah surat berharga, yaitu surat pengakuan utang, surat berharga komersial, saham, obligasi, tanda bukti utang, Unit Penyertaan Kontrak Investasi Kolektif, kontrak berjangka atas Efek, dan setiap derivatif dari Efek. (Pasal 1 angka 5 Undang-Undang Nomor 8 Tahun 1995, selanjutnya disebut Undang-Undang Pasar Modal).

${ }^{3}$ Sunariyah, Pengantar Pengetahuan Pasar Modal Indonesia, Cet. 2, UPP-AMP YKPN, Yogyakarta, 2000, hlm. 7-8. 
b. Pasar modal memberikan kesempatan kepada para investor untuk memperoleh hasil (return) yang diharapkan. Keadaan tersebut akan mendorong perusahaan (emiten) untuk memenuhi keinginan para investor untuk memperoleh hasil yang diharapkan;

c. Pasar modal memberikan kesempatan kepada investor untuk menjual kembali saham yang dimiliki atau surat berharga lainnya;

d. Pasar modal menciptakan kesempatan kepada masyarakat untuk berpartisipasi dalam perkembangan suatu perekonomian;

e. Pasar modal mengurangi biaya informasi dan transaksi surat berharga.

Instrumen pasar modal dapat dibedakan atas surat berharga yang bersifat utang (bonds atau obligasi) yang merupakan bukti pengakuan utang dari perusahaan dan surat berharga yang bersifat pemilikan (equity atau saham) yang merupakan bukti penyertaan modal dalam perusahaan. ${ }^{4}$ Dari sisi jangka waktu, surat utang dibedakan antara surat utang jangka pendek dan surat utang jangka menengah dan panjang. Di Indonesia, surat utang jangka pendek dengan jangka waktu sampai dengan satu tahun merupakan instrumen yang diperdagangkan di pasar uang dan tunduk pada ketentuan hukum yang dikeluarkan oleh Otoritas pasar uang, yaitu Bank Indonesia. Sedangkan surat utang yang berjangka waktu lebih dari satu tahun merupakan instrumen pasar modal dan tunduk pada ketentuan hukum yang dikeluarkan oleh Otoritas pasar modal (Badan Pengawas Pasar Modal dan Lembaga Keuangan, ${ }^{5}$ yang sejak tahun 2013 beralih menjadi Otoritas Jasa Keuangan ${ }^{6}$ ).

Jenis-jenis surat utang jangka pendek bervariasi antara satu Negara dengan Negara lain dan pada umumnya yang paling popular dikenal secara luas adalah Treasury Note, ${ }^{7}$

\footnotetext{
${ }^{4}$ Mohammad Irsan Nasarudin, Aspek Hukum Pasar Modal Indonesia, Cet. 4, Kencana Prenada Media Group, Jakarta, 2007, hlm. 181.

${ }^{5}$ Badan Pengawas Pasar Modal dan Lembaga Keuangan, yang selanjutnya disingkat menjadi Bapepam - LK, merupakan lembaga yang memiliki tugas pembinaan, pengaturan, dan pengawasan sehari-hari kegiatan pasar modal dengan tujuan mewujudkan terciptanya kegiatan pasar modal yang teratur, wajar dan efisien serta melindungi kepentingan pemodal dan masyarakat. (Undang-Undang Republik Indonesia Nomor 8 Tahun 1995 tentang Pasar Modal, sebagaimana diundangkan dalam Lembaran Negara Republik Indonesia Tahun 1995 Nomor 64 dan Tambahan Lembaran Negara Republik Indonesia Nomor 3608).

${ }^{6}$ Otoritas Jasa Keuangan, yang selanjutnya disingkat OJK, adalah lembaga yang independen dan bebas dari campur tangan pihak lain, yang mempunyai fungsi, tugas dan wewenang peraturan, pengawasan, pemeriksaan, dan penyidikan sebagaimana dimaksud dalam Undang-Undang ini. (Undang-Undang Republik Indonesia Nomor 21 Tahun 2011 tentang Otoritas Jasa keuangan sebagaimana diundangkan dalam Lembaran Negara Republik Indonesia Tahun 2011 Nomor 111 dan Tambahan Lembaran Negara Republik Indonesia Nomor 5253).

${ }^{7}$ Treasury Note is a note or bill issued by the treasury department by the authority of the United States government, and circulating as money. Henry Campbell Black, M.A., Black's Law Dictionary, Revised Fourth Edition, West Publishing Co., St. Paul Minnesota, hlm.1749. (selanjutnya disebut Black's Law Dictionary).
} 
Central Bank Bills (jika di Indonesia seperti Sertifikat Bank Indonesia ${ }^{8}$ atau Sertifikat Deposito Bank Indonesia ${ }^{9}$ ), Commercial Papers, ${ }^{10}$ Bankers acceptance. ${ }^{11}$ Sedangkan surat utang jangka menengah dikenal dengan Medium Term Notes (MTN) dan surat utang jangka panjang dikenal dengan obligasi (bond).

Karakteristik Obligasi dengan MTN hampir sama, namun MTN memiliki jangka waktu yang relatif lebih pendek daripada obligasi dan ditawarkan dengan bunga/kupon yang lebih besar daripada obligasi. Selain itu, MTN lebih fleksibel dalam proses penerbitannya daripada obligasi karena penerbit tidak perlu mendapatkan izin terlebih dahulu dari pihak Otoritas Jasa Keuangan (OJK). Produk ini sengaja diterbitkan oleh perusahaan yang memerlukan dana cepat yang periodenya lebih pendek daripada obligasi. Sebagai salah satu produk investasi di pasar modal, banyak perusahaan yang berkepentingan untuk menerbitkan MTN karena sifat struktur MTN itu sendiri yang dianggap cukup menarik, diantaranya tingkat suku bunga yang fleksibel dan relatif lebih rendah dari suku bunga kredit perbankan. Proses penerbitan MTN yang tidak terlalu rumit jika dibandingkan dengan prosedur pengajuan kredit perbankan maupun penerbitan obligasi juga menjadi daya tarik tersendiri bagi perusahaan yang sedang membutuhkan dana. Proses penerbitan MTN tidak memerlukan penawaran umum sehingga emiten tidak perlu menyiapkan dokumen-dokumen hukum secara lengkap setiap kali akan menerbitkan MTN seperti dalam penerbitan obligasi. Dapat dikatakan penerbitan MTN menjadi cara yang paling efisien untuk mengeluarkan surat utang jangka pendek baik dari segi waktu maupun biaya.

\footnotetext{
${ }^{8}$ Sertifikat Bank Indonesia yang selanjutnya disebut SBI adalah surat berharga dalam mata uang Rupiah yang diterbitkan oleh Bank Indonesia sebagai pengakuan utang berjangka waktu pendek. (Pasal 1 angka 7 Peraturan Bank Indonesia Nomor 18/12/PBI/2016 tentang Operasi Moneter sebagaimana diundangkan dalam Lembaran Negara Republik Indonesia Tahun 2016 Nomor 172 dan Tambahan Lembaran Negara Republik Indonesia Nomor 5919).

${ }^{9}$ Sertifikat Deposito Bank Indonesia yang selanjutnya disebut SDBI adalah surat berharga dalam mata uang Rupiah yang diterbitkan oleh Bank Indonesia sebagai pengakuan utang berjangka waktu pendek yang dapat diperdagangkan hanya antar-Bank. (Pasal 1 angka 8, Ibid).

${ }^{10}$ Commercial Paper adalah surat sanggup tanpa jaminan yang diterbitkan perusahaan bukan bank atau perusahaan efek, berjangka waktu pendek dan diperdagangkan dalam sistem diskonto. (Surat Keputusan Direksi Bank Indonesia Nomor 28/52/KEP/DIR tanggal 11 Agustus 1995).

${ }^{11}$ Banker's acceptance didefinisikan oleh Bank Indonesia sebagai Wesel Ekspor Berjangka (WEB) yang merupakan wesel ekspor yang diterbitkan oleh eksportir, yang memiliki jangka waktu tertentu dan telah diakseptasi oleh bank pengaksep di luar negeri. (Peraturan Bank Indoneaia Nomor 10/34/PBI/2008 tentang Transaksi Pembelian Wesel Ekspor Berjangka oleh Bank Indonesia sebagaimana diundangkan dalam Lembaran Negara Republik Indonesia Tahun 2008 Nomor 195 dan Tambahan Lembaran Negara Republik Indonesia Nomor 4942).
} 
Adapun beberapa keuntungan dan pertimbangan Emiten dalam menerbitkan MTN adalah sebagai berikut: ${ }^{12}$

a. Tidak ada controlling interest maupun campur tangan pemilik dana atau investor pembeli MTN terhadap perusahaan Emiten;

b. Akses pinjaman atau kredit Emiten ke Perbankan telah melebihi batasan atau limit kredit dari Bank-bank yang menjadi Kreditur Emiten, sehingga Emiten tidak bisa lagi memperoleh tambahan kredit dari Bank sedangkan Emiten sangat membutuhkan dana investasi untuk ekspansi usahanya;

c. Besaran suku bunga MTN biasanya dibawah suku bunga kredit perbankan, sehingga Emiten dapat memperkecil biaya operasionalnya;

d. Jangka waktu MTN dapat disesuaikan dengan arus kas (cashflow) dari Emiten, misalnya untuk kebutuhan dana sekitar 1 (satu) atau 2 (dua) tahun diterbitkan MTN dengan jangka waktu 1 (satu) atau 2 (dua) tahun atau bahkan lebih panjang hingga 5 (lima) tahun.

MTN ini merupakan instrumen investasi berpendapatan tetap (fixed income securities) yang mirip dengan Deposito, hanya saja berbeda dalam waktu pembayaran bunga dan jangka waktunya. Jangka waktu dalam Deposito yang biasanya ditawarkan perbankan kepada Nasabahnya terbagi dalam 1 (satu) bulanan, 3 (tiga) bulanan, 6 (enam) bulanan dan 1 (satu) tahun, sedangkan MTN biasanya berjangka waktu 1 (satu) sampai dengan 5 (lima) tahun. Dalam MTN, untuk pembayaran suku bunganya dikenal dengan istilah kupon yang biasanya telah ditetapkan dan diumumkan diawal pada masa penawaran yang dibayarkan secara rutin setiap 3 (tiga) bulan atau 6 (enam) bulan sekali.

Berdasarkan uraian tersebut, maka penting dilakukan pengkajian tentang pengaturan prosedur dan mekanisme pelaksanaan penerbitan MTN di Indonesia, risikorisiko yang ada dari MTN sebagai produk investasi, karakteristik perjanjian jual beli MTN, hubungan hukum para pihak dalam MTN beserta perlindungan hukum terhadap investor pembeli MTN apabila terjadi kerugian akibat risiko gagal bayar dari pihak penerbit MTN.

\section{Tujuan Penelitian}

Penelitian ini bertujuan untuk menganalisis tentang Karakteristik Perjanjian Jual Beli Medium Term Notes (MTN) dengan fokus pada hubungan hukum para pihak dalam MTN beserta perlindungan hukum terhadap investor pembeli MTN apabila terjadi kerugian akibat risiko gagal bayar dari pihak penerbit MTN.

\section{Manfaat Penelitian}

${ }^{12}$ Iman Syahputra, Hukum Pasar Modal, Haevarindo, Jakarta, 2011, hlm. 270 
Dari segi teoritik penelitian ini diharapkan berguna bagi pengembangan hukum Bisnis. Dari segi praktis penelitian ini diharapkan dapat berguna bagi praktik hukum dan penegakan hukum mengenai penanganan kasus atau permasalahan-permasalahan hukum yang berkaitan dengan Perjanjian Jual Beli Medium Term Notes (MTN).

\section{Metode Penelitian}

Penelitian ini merupakan penelitian hukum normatif, yaitu penelitian terhadap bahan hukum primer dan bahan hukum sekunder yang terdiri dari peraturan perundang-undangan dan regulasi yang berlaku dan berkaitan dengan masalah dalam yang sedang diteliti bertujuan mencari pemecahan atas isu hukum yang timbul didalamnya, sehingga hasil yang dicapai adalah memberikan preskripsi mengenai apa yang seyogyanya atas isu hukum yang diajukan. Pendekatan yang digunakan adalah pendekatan perundang-undangan (statute approach), pendekatan konseptual (conceptual approach), dan pendekatan kasus (case approach). ${ }^{13}$ Metode analisis bahan hukum didasarkan pada bahan hukum primer berupa perundangan-undangan dikumpulkan dengan metode inventarisasi dan kategorisasi.

\section{B. PEMBAHASAN}

\section{Hubungan Hukum Para Pihak Dalam Perjanjian Jual Beli Medium Term Notes (MTN)}

Dalam Peraturan Otoritas Jasa Keuangan Nomor 3/POJK.05/2015 tentang Investasi Dana Pensiun, ${ }^{14}$ Medium Term Notes atau yang disingkat MTN didefinisikan sebagai surat utang yang diterbitkan oleh perusahaan dan memiliki jangka waktu satu sampai dengan lima tahun serta terdaftar di Kustodian Sentral Efek Indonesia (KSEI). ${ }^{15}$ MTN merupakan surat berharga yang menunjukkan bahwa penerbit MTN meminjam sejumlah dana kepada masyarakat dan memiliki kewajiban untuk membayar bunga secara berkala dan kewajiban melunasi pokok utang pada waktu yang telah ditentukan kepada pihak pembeli MTN tersebut. Berdasarkan uraian tersebut, MTN merupakan surat berharga

${ }^{13}$ Peter Mahmud Marzuki, Penelitian Hukum, Kencana Prenada Media Group, Jakarta, 2005, hlm. 113

${ }^{14}$ Peraturan Otoritas Jasa Keuangan Nomor 3/POJK.05/2015 tentang Investasi Dana Pensiun sebagaimana diundangkan dalam Lembaran Negara Republik Indonesia Tahun 2015 Nomor 82, Tambahan Lembaran Negara Republik Indonesia Nomor 5692

${ }^{15}$ KSEI atau PT Kustodian Sentral Efek Indonesia merupakan perseroan yang telah memperoleh izin usaha dari Bapepam untuk menyelenggarakan kegiatan usaha sebagai Lembaga Penyimpanan dan Penyelesaian. (Keputusan Direksi PT Kustodian Sentral Efek Indonesia Nomor: KEP-0013/DIR/KSEI/0612 tentang Perubahan Peraturan Jasa Kustodian Sentral). 
yang bersifat utang dan termasuk ke dalam jenis surat sanggup atau promes maka dalam penelitian ini digunakan teori-teori terkait dengan hukum surat berharga, baik dari definisi surat berharga sebagai surat bukti tuntutan utang pembawa hak dan mudah diperjualbelikan.

Ketentuan dalam Pasal 1 angka 10 Undang-Undang Perbankan merumuskan pengertian surat berharga yaitu "Surat Berharga adalah surat pengakuan hutang, wesel, saham, obligasi, sekuritisasi kredit, atau setiap derivatifnya, atau kepentingan lain, atau suatu kewajiban dari penerbit, dalam bentuk yang lazim diperdagangkan dalam pasar modal dan pasar uang". Jadi secara sederhana surat berharga dapat diartikan sebagai suatu dokumen atau surat yang didalamnya memuat suatu kesanggupan, janji, atau perintah tidak bersyarat untuk membayar sejumlah uang tertentu pada waktu tertentu pula, yang diperuntukkan sebagai alat pembayaran atau jaminan dan serta dibuat dengan sengaja untuk dapat diperjualbelikan atau diperdagangkan. Penerbitan, pembelian maupun penjualan surat pengakuan hutang juga menjadi kegiatan usaha perbankan melalui pasar uang maupun pasar modal. Hal tersebut diatur dalam Pasal 6 huruf c dan d Undang-Undang Perbankan.

Surat Berharga adalah surat yang oleh penerbitnya sengaja diterbitkan sebagai pelaksanaan pemenuhan suatu prestasi, yang berupa pembayaran sejumlah uang tetapi pembayaran tersebut tidak dilakukan dengan menggunakan mata uang melainkan dengan menggunakan alat bayar lain. ${ }^{16}$ Alat bayar yang dimaksud berupa surat yang di dalamnya mengandung suatu perintah kepada pihak ketiga, atau pernyataan sanggup untuk membayar sejumlah uang kepada pemegang surat tersebut. ${ }^{17}$ Dengan diterbitkannya surat tersebut oleh penerbit, maka pemegang surat memiliki hak untuk memperoleh pembayaran dengan jalan menunjukkan dan menyerahkan surat itu kepada pihak ketiga atau kepada pihak yang menyanggupi tersebut. Dengan kata lain, pemegang surat itu mempunyai hak tagih atas sejumlah uang yang tersebut di dalamnya.

Hak tagih itu kemudian dapat dialihkan kepada pemegang berikutnya, baik dengan cara penyerahan suratnya dari tangan ke tangan maupun dengan cara membuat suatu pernyataan atau akta pada surat itu untuk kemudian surat itu diserahkan kepada pemegang surat berikutya. ${ }^{18}$ Fungsi sebagai alat untuk memindahkan hak tagih dapat diartikan bahwa

\footnotetext{
${ }^{16}$ Abdulkadir Muhammad, Hukum Dagang Tentang Surat-Surat Berharga, Citra Aditya Bakti, Bandung,
} 1998, hlm. 5 .

17 Ibid.

${ }^{18}$ Ibid. 
surat berharga tersebut dapat diperjualbelikan atau dipindahtangankan kepada pemegang berikutnya setiap saat apabila dikehendaki oleh pemegangnya. Pemindahtanganan itu cukup dengan menyerahkan suratnya saja atau dengan menuliskan keterangan pada surat itu bahwa hak tagihnya dipindahkan kemudian ditandatangani dan diserahkan. Cara peralihan hak tagih itu dapat diketahui dari klausula yang terdapat dalam surat berharga iu apakah klausula atas unjuk atau atas pengganti.

Sehingga perikatan dasar menjadi latar belakang diterbitkannya surat berharga oleh penerbit sebagai pemenuhan isi perjanjian. Apabila pemegang surat berharga itu mengalihkan kepemilikannya kepada pemegang berikutnya, maka timbul pertanyaan apakah yang menjadi dasar hukum surat berharga tersebut mengikat antara penerbit dengan pemegang yang bukan meruapakan pemegang pertama kali. Terdapat empat teori yang membahas permasalahan tersebut, yaitu:
a. Teori kreasi atau penciptaan (creatietheorie); ${ }^{19}$
b. Teori kepantasan (redelijkheid stheorie), ${ }^{20}$
c. Teori perjanjian (overeenkomsttheorie); ${ }^{21}$
d. Teori penunjukan (vertoningstheorie). ${ }^{22}$

Secara rinci, berikut disampaikan beberapa perbedaan pokok antara MTN dengan Obligasi yang diambil dari berbagai sumber:

\begin{tabular}{|c|l|l|}
\hline No & \multicolumn{1}{|c|}{ Obligasi } & \multicolumn{1}{c|}{ Medium Term Notes (MTN) } \\
\hline 1 & $\begin{array}{l}\text { Surat Utang yang memiliki jangka } \\
\text { maktu menengah hingga relatif } \\
\text { (umumnya diatas 3 tahun) }\end{array}$ & $\begin{array}{l}\text { Surat Utang yang memiliki jangka waktu } \\
\text { pendek hingga menengah (umumnya tidak } \\
\text { lebih dari satu sampai dengan lima tahun) }\end{array}$ \\
\hline 2 & $\begin{array}{l}\text { Memerlukan pernyataan efektif dari } \\
\text { OJK }\end{array}$ & $\begin{array}{l}\text { Tidak memerlukan pernyataan efektif dari } \\
\text { OJK }\end{array}$ \\
\hline 3 & $\begin{array}{l}\text { Setelah memperoleh pernyataan } \\
\text { efektif, penawaran obligasi dapat } \\
\text { dilakukan sekaligus atau berkelanjutan } \\
\text { (sesuai persetujuan yang diberikan oleh } \\
\text { OJK). } \\
\text { Penawaran dilakukan melalui } \\
\text { penawaran umum (tidak ada } \\
\text { pembatasan investor) }\end{array}$ & $\begin{array}{l}\text { Penawan kepada investor dilakukan } \\
\text { kepada 100 (seratus) pihak atau calon } \\
\text { investor dan realisasi investor kurang dari } \\
\text { dapat dilakukan sesuai dengan proyek } \\
\text { yang ditawarkan (tanpa penawaran } \\
\text { umum) }\end{array}$ \\
\hline
\end{tabular}

\footnotetext{
${ }^{19}$ Ibid., hlm. 16

${ }^{20}$ Ibid., hlm. 17

${ }^{21}$ Ibid.

${ }^{22}$ Ibid., hlm. 18
} 


\begin{tabular}{|c|l|l|}
\hline 4 & $\begin{array}{l}\text { Dokumentasi lebih kompleks } \\
\text { mengikuti ketentuan pasar modal } \\
\text { sehingga bagi penerbit memerlukan } \\
\text { biaya yang lebih besar }\end{array}$ & $\begin{array}{l}\text { Dokumentasi lebih sederhana dan waktu } \\
\text { penerbitan 9elative lebih mudah } \\
\text { disesuaikan dengan kebutuhan cash flow } \\
\text { penerbit }\end{array}$ \\
\hline 5 & $\begin{array}{l}\text { Wajib didaftarkan di KSEI sehingga } \\
\text { lebih aman diperdagangkan di pasar } \\
\text { sekunder tanpa } \\
\text { scriptless/paperless) }\end{array}$ & Tidak wajib didaftarkan di KSEI \\
\hline 6 & $\begin{array}{l}\text { Wajib dicatatkan di Bursa Efek } \\
\text { sehingga lebih likuid }\end{array}$ & $\begin{array}{l}\text { Tidak wajib dicatatkan di Bursa Efek } \\
\text { sehingga relative kurang likuid }\end{array}$ \\
\hline 7 & $\begin{array}{l}\text { Rating surat berharga wajib ada } \\
\text { Rating surat berharga tidak wajib ada }\end{array}$ \\
\hline 8 & $\begin{array}{l}\text { Laporan keuangan audited terakhir } \\
\text { yang tidak boleh lebih dari 6 bulan dari } \\
\text { tanggal efektif OJK dan diperlukan } \\
\text { comfort letter dari Kantor Akuntan } \\
\text { Publik }\end{array}$ & $\begin{array}{l}\text { Laporan keuangan audited terakhir dan in- } \\
\text { house (unaudited) terakhir serta tidak } \\
\text { diperlukan comfort letter dari Kantor } \\
\text { Akuntan Publik }\end{array}$ \\
\hline 9 & $\begin{array}{l}\text { Kupon obligasi cenderung lebih rendah } \\
\text { karena jumlah investor tidak dibatasi } \\
\text { dan Penerbit sudah mengeluarkan } \\
\text { biaya yang lebih besar serta } \\
\text { memerlukan proses yang lebih panjang }\end{array}$ & $\begin{array}{l}\text { Kupon MTN umumnya lebih tinggi, } \\
\text { karena jumlah investor terbatas, proses } \\
\text { penerbitan lebih pendek dan lebih } \\
\text { sehingga biaya yang dikeluarkan Penerbit } \\
\text { lebih murah }\end{array}$ \\
\hline
\end{tabular}

Dalam melakukan penerbitan MTN, tidak terlepas dari beberapa pihak yang berperan antara lain:

a. Emiten

Pasal 1 angka 6 Undang-Undang Pasar Modal mendefinisikan Emiten sebagai pihak yang melakukan penawaran umum. Secara sederhana, Emiten dapat disebut juga sebagai pihak yang membutuhkan dana sehingga berhutang pada pembeli MTN. Dapat dikatakan Emiten tidak memiliki money in cash atau uang tunai sehingga harus berhutang.

b. Penjamin Emisi Efek

Pasal 1 Angka 17 Undang-Undang Pasar Modal memberikan definisi atas Penjamin Emisi Efek yaitu "pihak yang membuat kontrak dengan Emiten untuk melakukan penawaran umum bagi kepentingan Emiten dengan atau tanpa kewajiban untuk membeli

${ }^{23}$ Comfort Letter adalah surat yang dibuat oleh Akuntan yang menyatakan ada atau tidaknya fakta material yang terjadi setelah tanggal laporan keuangan terakhir sampai dengan menjelang tanggal efektifnya Pernyataan Pendaftaran yang dapat mengakibatkan perubahan signifikan atau membahayakan posisi keuangan atau hasil usaha sebagaimana disajikan dalam laporan keuangan yang dilampirkan sebagai dokumen Pernyataan Pendaftaran dan dimuat dalam Prospektus. Peraturan Nomor VIII. G.5, Lampiran Keputusan Ketua Badan Pengawas Pasar Modal Nomor Kep-41/PM/1996 tanggal 17 Januari 1996 tentang Pedoman Penyusunan Comfort Letter. 
sisa Efek yang tidak terjual". Penjamin Emisi Efek merupakan mediator antara Emiten dengan calon Investor. Tugas utama Penjamin Emisi dalam penerbitan Efek adalah mengusahakan agar penjualan Efek kepada calon Investor berjalan dengan lancar dengan harapan semua Efek terjual kepada Investor. Dalam kegiatan ini, dikenal beberapa jenis dan cara penjaminan emisi sebagai berikut: ${ }^{24}$

1) Kesanggupan penuh (full commitment underwriting)

Perjanjian emisi efek dimana penjamin emisi efek mengikat diri untuk menawarkan efek kepada masyarakat dan akan menjadi pembeli sisa efek yang tidak laku terjual dengan harga yang sama dengan harga penawaran pada pasar perdana.

2) Kesanggupan terbaik (best effort commitment)

Penjamin emisi efek akan berusaha semaksimal mungkin menjual efek yang diterbitkan oleh Emiten. Apabila dalam penawaran umum di pasar perdana, terdapat sisa efek yang tidak laku terjual maka pihak penjamin emisi efek tidak wajib membelinya dengan mengembalikan sisa efek yang tidak terjual kepada pihak Emiten.

3) Kesanggupan siaga (standby commitment)

penjamin emisi efek berusaha menawarkan efek semaksimal mungkin kepada calon pemodal. Kemudian jika setelah masa penawaran umum di pasar perdana terdapat sisa efek yang belum terjual sampai batas waktu penawaran yang telah ditetapkan, maka penjamin emisi efek memberikan kesanggupan untuk membeli sisa efek tersebut dengan harga tertentu sesuai dengan perjanjian dengan Emiten yang besarnya di bawah harga penawaran pada pasar perdana.

4) Kesanggupan semua atau tidak sama sekali (all or none commitment)

Komitmen ini menyatakan jika efek yang ditawarkan ternyata sebagian tidak terjual, maka penjualan efek tersebut dinyatakan batal sama sekali. Artinya, bagian efek yang telah laku dipesan akan dibatalkan penjualannya dan semua sisa efek dikembalikan kepada Emiten. Dalam konteks ini dikenal istilah komitmen minimum atau maksimum. Penjualan efek yang telah mencapai batas minimum penjualan yang telah ditentukan, maka penjamin emisi efek dapat meneruskan penawaran sampai dengan batas maksimum penjualan. Akan tetapi, apabila dalam batas waktu tertentu efek yang belum terjual belum memenuhi ketentuan jumlah minimum, maka penjualan efek dibatalkan.

\section{Wali Amanat (Trustee)}

Pengertian Wali Amanat menurut Pasal 1 angka 30 Undang-Undang Pasar Modal adalah “pihak yang mewakili kepentingan pemegang efek yang bersifat utang”. Oleh karena efek bersifat utang merupakan surat pengakuan utang yang bersifat sepihak dari pihak Emiten dengan Kreditur yang jumlahnya lebih dari satu, maka perlu dibentuk suatu

${ }^{24}$ Iskandar Z. Alwi, Pasar Modal Teori dan Aplikasi, Yayasan Pancur Siwah, Jakarta, 2003, h. 26 
lembaga yang mewakili kepentingan seluruh Kreditur. Tugas dan tanggung jawab Wali Amanat berdasarkan Keputusan Ketua Badan Pengawas Pasar Modal dan Lembaga Keuangan Nomor KEP-412/BL/2010 tentang Ketentuan Umum dan Kontrak Perwaliamanatan Efek Bersifat utang adalah sebagai berikut:

1) Mewakili kepentingan para pemegang efek bersifat utang, baik di dalam maupun di luar pegadilan sesuai dengan Kontrak Perwaliamanatan dan peraturan perundang-undangan;

2) Mengikatkan diri untuk melaksanakan tugas pokok dan tanggung jawab sebagaimana dimaksud dalam poin a diatas sejak menandatangani Kontrak Perwaliamanatan dengan Emiten, tetapi perwakilan tersebut mulai berlaku efektif pada saat efek bersifat utang telah dialokasikan kepada pemodal;

3) Melaksanakan tugas sebagai Wali Amanat berdasarkan Kontrak Perwaliamanatan dan dokumen lainnya yang berkaitan dengan Kontrak Perwaliamanatan

4) Memberikan semua keterangan atau informasi sehubungan dengan pelaksanaan tugas perwaliamanatan kepada OJK.

4. Investor (Pemodal)

Investor sebagai pihak yang menginventarisasikan dananya di pasar modal, dengan cara membeli efek yang bersifat utang maupun efek yang bersifat ekuitas. Investor yang terlibat dalam pasar modal Indonesia adalah investor domestik dan asing, perorangan dan institusi. ${ }^{25}$

5. Lembaga Penyelesaian dan Penyimpanan

Lembaga penyelesaian dan penyimpanan ini dilaksanakan oleh PT Kustodian Sentral Efek Indonesia (KSEI). Perusahaan ini berfungsi sebagai lembaga penyelesaian transaksi dan penyimpanan efek yang diperjual-belikan bauk melalui bursa maupun di luar bursa. Mengingat MTN tidak terdaftar di bursa, maka penyelesaian transaksi dilakukan oleh masing-masing pihak yang bertransaksi dan berhubunganlangsung dengan KSEI untuk proses perpindahan kepemilikan dan penyimpanan efek. KSEI memberikan layanan jasa penyimpanan dan penyelesaian transaksi efek yang meliputi penyimpanan efek dalam bentuk elektronik, penyelesaian transaksi efek, administrasi rekening efek, distribusi hasil corporate action dan jasa-jasa terkait lainnya. ${ }^{26}$

6. Profesi Penunjang Pasar Modal

\footnotetext{
${ }^{25}$ Gunawan Widjaja dan Jono, Penerbitan Obligasi dan Peran serta Tanggung Jawab Wali Amanat dalam Pasar Modal, Kencana Prenada Media Group, Jakarta, 2006, hlm. 51

${ }^{26}$ Tarmiden Sitorus, Pasar Obligasi Indonesia: Teori dan Praktik, Rajagrafindo Persada, Jakarta, 2015, hlm. 161 .
} 
Profesi Penunjang Pasar Modal terdiri dari Akuntan Publik, Konsultan Hukum dan Notaris. Akuntan publik merupakan profesi penunjang pasar modal yang berfungsi memeriksa kondisi keuangan Emiten serta memberikan pendapatnya tentang kelayakan Emiten dalam menerbitkan efek. Konsultan Hukum yang ditunjuk oleh Emiten berperan sebagai legal drafter and adviser.

Menurut R. Soeroso, hubungan hukum adalah hubungan antara dua atau lebih subjek hukum. Dalam hubungan hukum ini hak dan kewajiban pihak yang satu akan berhadapan dengan hak dan kewajiban pihak yang lain. ${ }^{27}$ Hubungan hukum ini dapat tercipta dari perikatan yang timbul dari perjanjian atau Undang-Undang. Hubungan hukum yang terjadi atas penerbitan MTN adalah hubungan hukum emiten dengan Perusahaan Efek, emiten dengan profesi penunjang, emiten dengan investor dan emiten dengan Wali Amanat (jika penerbitannya menggunakan Wali Amanat).

Mekanisme perdagangan surat berharga di Indonesia dapat terjadi melalui: ${ }^{28}$

a. Pasar Primer

Merupakan kegiatan penawaran dan penjualan surat utang untuk pertama kali pada saat penerbitan, yang dapat dilakukan baik secara penawaran umum (initial public offering/IPO) maupun penjualan langsung (private placement).

b. Pasar Sekunder

Merupakan kegiatan perdagangan surat berharga yang telah dijual di pasar primer baik melalui bursa atau non-bursa dan biasa disebut over the counter. Transaksi ini dapat berulang terus menerus diantara para Investor. Perpindahan efek dari tangan Investor Jual dan Investor Beli diikuti perubahan harga dari efek yang diperdagangkan sesuai dengan harga yang disepakati oleh kedua belah pihak.

MTN merupakan surat berharga yang di dalamnya memuat pernyataan berutang dari pihak penerbit kepada pemegang MTN dan menyanggupi untuk membayar atau mengembalikan sejumlah pokok dengan bunga tertentu sebagaimana disebutkan dalam surat utang itu. MTN pada prinsipnya adalah bukti atas suatu prestasi dari penerbit kepada pemegangnya sehingga antara Penerbit dengan pemegang MTN terdapat suatu perikatan. Perikatan tersebut mengakibatkan timbulnya kewajiban untuk melaksanakan suatu prestasi pada pihak penerbit dan timbulnya hak pada pihak pemegang MTN. Jadi, apabila orang membeli MTN, berarti orang tersebut memberi pinjaman uang untuk jangka waktu tertentu dengan bunga tertentu dan pinjaman tersebut akan dibayar lunas oleh pihak penerbit sesuai

\footnotetext{
${ }^{27}$ R. Soeroso, Pengantar Ilmu Hukum, Sinar Grafika, Jakarta, 2001, hlm. 269.

${ }^{28}$ Tarmiden Sitorus, Op. Cit, hlm, 135.
} 
dengan jangka waktu yang tercantum dalam MTN. Sebagai konsekuensi dari konstruksi bahwa perikatan penerbit dan pemegang MTN adalah perikatan pinjam-meminjam uang, maka pemegang MTN merupakan Kreditur atas sejumlah uang yang dipinjamkannya kepada penerbit MTN.

Sedangkan penerbit merupakan debitur atas sejumlah uang yang dipinjamkannya kepada pemegang MTN. MTN pada dasarnya adalah utang-piutang. ${ }^{29}$ Piutang sebagai benda kalau dijadikan obyek Perjanjian Jual Beli, sebagaimana biasanya pihak penjual selain harus melaksanakan kewajiban utamanya melakukan levering (penyerahan) juga harus menanggungnya bahwa hak itu benar ada sebagaimana yang dinyatakan oleh Pasal $1534 \mathrm{BW}^{30}$ Sehingga suatu efek dapat dipindahtangankan atau menjadi suatu alat pembayaran/transaksi. ${ }^{31}$ Suatu efek biasanya dialihkan kepada pihak lain dengan tujuan agar mendapatkan uang dengan cepat. Hal ini dilakukan dengan menjual efek tersebut kepada pihak lain.

Selanjutnya akan dibahas mengenai penyerahan surat berharga. Sebagaimana Pasal $613 \mathrm{BW}$ yang menyebutkan bahwa terdapat cara penyerahan untuk jenis surat berharga antara lain Cessie, Subrogasi dan Novasi. Pada MTN yang berada di dalam pasar modal merupakan MTN atas nama, sehingga dapat diketahui siapa saja Kreditor dari Emiten yang telah melepaskan MTN tersebut. Berdasarkan ciri dan ketentuan dalam 3 jenis pengalihan Kreditor, maka cara yang paling tepat dalam pengalihan Kreditor di dalam pasar modal adalah menggunakan cessie. Cessie merupakan cara penyerahan/peralihan piutang/surat berharga atas nama. Untuk benda-benda tak berwujud yang tergolong sebagai benda bergerak yang merupakan piutang atas nama dan benda-benda lain yang tak bertubuh penyerahannya dilakukan dengan pembuatan suatu akta baik berupa akta otentik ataupun berupa akta di bawah tangan kemudian memberitahukan penyerahan tersebut kepada debitur (pihak yang berutang) yang bersangkutan. Hal ini dikarenakan di dalam cessie terdapat pengalihan piutang dari Kreditor lama kepada Kreditor baru melalui cara jual beli piutang.

\section{Bentuk Perlindungan Hukum Terhadap Investor Pemegang Medium Term Notes (MTN)}

${ }^{29}$ Adrian Sutedi, Aspek Hukum Obligasi dan Sukuk, Sinar Grafika, Jakarta, 2009, hlm. 13.

${ }^{30}$ Moch. Isnaeni, Perjanjian Jual Beli, Revka Petra Media, Surabaya, 2015, hlm. 220.

${ }^{31}$ Sri Soedewi Masjchoen Sofwan, Hukum Perdata Hukum Perutangan, Fakultas Hukum Universitas Yogyakarta, 1980, hlm. 88. 
Tingkat risiko investasi berbeda-beda antara satu efek dengan efek lainnya tergantung pada karakteristik dari efek yang bersangkutan. Efek obligasi maupun MTN tetap mempunyai risiko meskipun relatif lebih rendah risikonya daripada efek ekuitas. Risiko gagal bayar merupakan hal yang mungkin terjadi, walaupun hal ini merupakan pelanggaran terhadap perjanjian yang telah disepakati oleh Debitur (Emiten) dan Kreditur (Investor). Besar kecilnya risiko gagal bayar ini akan mempengaruhi tingkat suku bunga yang ditawarkan oleh suatu efek obligasi atau MTN. Dalam dunia keuangan dikenal sebuah istilah "no risk no return, high risk high return" yang artinya semakin kecil suatu risiko investasi maka semakin kecil imbal hasil yang akan diperoleh, dan sebaliknya semakin tinggi risiko suatu investasi, maka imbal hasil yang diharapkan juga semakin besar.

Secara umum risiko keuangan dapat diartikan sebagai kemungkinan kerugian sebagian atau seluruh investasi, atau dengan perkataan lain imbal hasil yang diperoleh (actual return) dari suatu investasi tidak sesuai dengan yang diharapkan (expected return). Risiko juga diartikan sebagai potensi kerugian akibat terjadinya suatu peristiwa tertentu. ${ }^{32}$ OJK menetapkan 8 (delapan) jenis risiko yang melekat dalam aktivitas perbankan antara lain risiko kredit, risiko pasar, risiko likuiditas, risiko operasional, risiko hukum, risiko reputasi, risiko stratejik dan risiko kepatuhan. ${ }^{33}$

Dalam melakukan transaksi dalam pasar modal, setiap pihak menginginkan jaminan dan hal tersebut diwujudkan dalam kalusul-klausul yang disepakati baik dengan lisan maupun dengan perjanjian tertulis dengan tujuan untuk mengamankan transaksi bagi semua pihak yang terlibat. Perlindungan hukum sebagai salah satu aspek dalam bidang hukum yang memberikan kepastian hukum terhadap subjek hukum sehingga dapat tercapai tujuan dari dibuatnya hukum tersebut. Menurut Philipus M. Hadjon, perlindungan hukum diartikan sebagai suatu usaha untuk memberikan hak-hak pihak yang dilindungi sesuai dengan kewajiban yang telah dilakukan. Namun juga bisa diartikan sebagai kumpulan peraturan atau kaidah yang akan dapat melindungi suatu hal dari hal lainnya. ${ }^{34}$ Berkaitan dengan konsumen, berarti hukum memberikan perlindungan terhadap hak-hak pelanggan dari sesuatu yang mengakibatkan tidak terpenuhinya hak-hak tersebut. Menurut Philipus M.

\footnotetext{
${ }^{32}$ Pasal 1 angka 2 Peraturan Otoritas Jasa Keuangan nomor 18/POJK.03/2016 tentang Penerapan Manajemen Risiko Bagi Bank Umum

${ }^{33}$ Pasal 1 angka 4 -11 Peraturan Otoritas Jasa Keuangan nomor 18/POJK.03/2016 tentang Penerapan Manajemen Risiko Bagi Bank Umum.

${ }^{34}$ Philipus M. Hadjon, Perlindungan Hukum Bagi Rakyat Indonesia, Bina Ilmu, Jakarta, 1978. hlm. 2
} 
Hadjon, ${ }^{35}$ perlindungan hukum bagi rakyat meliputi 2 (dua) hal, yaitu Perlindungan Hukum Preventif (pencegahan) dan Perlindungan Hukum Represif (pemaksaan).

Berikut ini diuraikan perlindungan hukum preventif yang dapat diambil:

a. Pemeringkatan surat utang

Pelaku pasar modal yang ingin berinvestasi pada surat utang pada umumnya memperhatikan peringkat kredit (credit rating) dari suatu efek surat utang untuk menentukan harga atau suku bunga yang diminta. Peringkat surat utang merupakan skala risiko dari semua surat utang yang diperdagangkan dan memberikan pernyataan yang informatif serta memberikan sinyal tentang probabilitas kegagalan utang suatu perusahaan. ${ }^{36}$ Agen pemeringkat surat utang merupakan lembaga independen yang memberi informasi pemeringkatan skala rasio utang sebagai petunjuk seberapa aman suatu surat utang bagi investor. Dalam rangka memperoleh gambaran mengenai kualitas dari suatu surat utang, dilakukan assessment secara komprehensif terhadap Emiten. Penilain dilakukan dengan melakukan diskusi dengan pihak senior manajemen mencakup aspek-aspek seperti latar belakang dan sejarah perusahaan, strategi dan filosofi perusahaan, posisi perusahaan yang mencakup daya saing, kapasitas produksi, jaringan distribusi dan pemasokan serta pemasaran, pengelolaan keuangan dan kewajiban lainnya serta topik relevan lainnya. Tidak seperti Obligasi, instrumen MTN tidak dipersyaratkan wajib untuk dilakukan pemeringkatan oleh Lembaga Pemeringkat sehingga biaya yang dikeluarkan Emiten cukup kecil. Demi menjamin keamanan MTN, sebaiknya pemeringkatan surat utang tetap dilakukan.

3. Pelaksanaan prinsip keterbukaan informasi

Undang-Undang Pasar Modal juga menganut mengenai prinsip keterbukaan, yang didefinisikan sebagai pedoman umum yang mensyaratkan Emiten, untuk menginformasikan kepada masyarakat dalam waktu yang tepat seluruh Informasi Material mengenai usahanya atau efeknya yang dapat berpengaruh terhadap keputusan Pemodal dan atau harga dari efek tersebut. Informasi atau Fakta Material adalah informasi atau fakta penting dan relevan mengenai peristiwa, kejadian atau fakta yang dapat mempengaruhi harga efek pada Bursa Efek dan/atau keputusan pemodal, calon

\footnotetext{
${ }^{35}$ Ibid, hlm. 4

${ }^{36}$ Wydia Andry, Analisis Faktor - Faktor yang Mempengaruhi Prediksi Peringkat Obligasi, Buletin
} Ekonomi Moneter dan Perbankan, September 2005. 
pemodal atau pihak lain yang berkepentingan atas informasi atau fakta tersebut ${ }^{37}$ Bentuk lain pelaksanaan prinsip keterbukaan dalam penerbitan MTN dapat diwujudkan dengan pembuatan Info Memo. Dalam praktiknya, Emiten yang menerbitkan MTN biasanya menerbitkan Info Memo yang akan diberikan kepada Calon emiten pada masa penawaran. Info Memo adalah dokumen tertulis yang memuat seluruh informasi dalam Prospektus Awal dan informasi tambahan lain yang relevan (jika ada) dan ditulis dalam bahasa lain selain Bahasa Indonesia, serta dapat dibuat dalam format yang berbeda. ${ }^{38} \mathrm{Di}$ dalam Info Memo, dapat dicantumkan informasi minimum yang perlu diketahui Investor antara lain mengenai kisaran jumlah Efek yang akan ditawarkan, kisaran harga penawaran Efek, dan hal lain yang berhubungan dengan persyaratan penawaran. Pentingnya Info Memo dalam pelaksanaan prinsip keterbukaan, karena mengandung kebenaran formil dan kebenaran materiil tentang Perusahaan Penerbit dan usahanya sehingga isinya tidak boleh memberikan gambaran yang menyesatkan dan mengakibatkan keputusan yang diambil oleh Investor tidak tepat. Namun demikian, tidak diatur secara jelas bahwa Emiten yang menerbitkan MTN untuk memenuhi kewajiban keterbukaan informasi baik sebelum penawaran maupun setelah masa penawaran.

\section{Wali Amanat}

Peran Wali Amanat sangat diperlukan mengingat Wali Amanat merupakan pihak yang secara profesional khusus ditunjuk untuk melakukan pengawasan bagi kepentingan seluruh kreditur efek bersifat utang.

Sebagai bentuk perlindungan hukum represif, MTN disertai dengan jaminan dalam penerbitannya. Dalam hal jaminan pada umumnya MTN tidak dijamin secara khusus baik karena tidak adanya peraturan yang mewajibkan adanya jaminan dalam penerbitan MTN. Jaminan yang melekat pada MTN untuk seluruh pinjaman adalah jaminan umum atas seluruh harta kekayaan perseroan baik barang bergerak maupun tidak bergerak, baik yang telah ada maupun yang akan ada di kemudian hari sesuai dengan ketentuan Pasal 1131 dan 1132 BW. Dalam hal ini kedudukan Pemegang MTN hanyalah sebatas Kreditor biasa atau konkuren yaitu hak pemegang MTN adalah paripassu tanpa hak preferen dengan hak-hak

\footnotetext{
${ }^{37}$ Pasal 1 Angka 7 Undang Undang Pasar Modal.

${ }^{38}$ Pasal 1 Angka 3 Peraturan Otoritas Jasa Keuangan Nomor 23/POJK.04/2017 tentang Prospektus Awal dan Info Memo
} 
kreditur Perseroan lainnya baik yang ada sekarang maupun dikemudian hari, kecuali hakhak kreditur Perseroan yang dijamin secara khusus dengan kekayaan perseroan baik yang telah ada maupun yang akan ada dikemudian hari. Apabila terjadi gagal bayar dari Emiten, maka pemegang MTN hanya mendapatkan pelunasan secara proporsional. Sehingga diperlukan peran aktif dari Investor pemegang MTN untuk melindungi kepentingannya sendiri selaku pemegang MTN.

\section{PENUTUP}

\section{Kesimpulan}

Pengaturan MTN yang diterbitkan selama ini di Indonesia merupakan pengaturan yang berdasarkan pada hukum perjanjian, terutama prinsip-prinsip tentang pinjam meminjam uang (verbruiklening) dan jual beli dalam BW khususnya Buku Ketiga sejauh masih relevan dengan suatu penerbitan MTN serta hukum surat berharga dalam KUHD khususnya tentang Surat Sanggup. MTN merupakan surat berharga yang di dalamnya memuat pernyataan berutang dari pihak penerbit kepada pemegang MTN dan menyanggupi untuk membayar atau mengembalikan sejumlah pokok dengan bunga tertentu sebagaimana disebutkan dalam surat utang itu. MTN pada prinsipnya adalah bukti atas suatu prestasi dari penerbit kepada pemegangnya sehingga antara Penerbit dengan pemegang MTN terdapat suatu perikatan yaitu pinjam meminjam uang. Sebagai konsekuensi dari konstruksi bahwa perikatan penerbit dan pemegang MTN adalah perikatan pinjam-meminjam uang, maka pemegang MTN merupakan Kreditur atas sejumlah uang yang dipinjamkannya kepada penerbit MTN. Sedangkan penerbit merupakan debitur atas sejumlah uang yang dipinjamkannya kepada pemegang MTN. MTN pada dasarnya adalah utang-piutang dapat dipindahtangankan atau menjadi suatu alat pembayaran/transaksi (sebagai obyek Perjanjian Jual Beli). Penggantian pihak Kreditor di dalam perjanjian MTN, dapat dilakukan melalui cessie.

\section{Saran}

Salah satu tujuan penerbitan MTN adalah untuk menghimpun dana dari masyarakat, sehingga sangat penting adanya pengaturan yang jelas mengenai MTN yang dapat melindungi kepentingan pemegang MTN. Pengaturan tersebut tidak hanya ditujukan kepada Emiten saja, namun juga terhadap seluruh pihak yang terlibat dalam penerbitan suatu MTN seperti Perusahaan Efek yang bertindak sebagai Arranger, Agen Pemantau dan 
Penjamin, Wali Amanat, dan agen Pembayaran yaitu KSEI. Selain itu diperlukan pengawasan yang efektif dari otoritas yang berwenang untuk dapatnya mengawasi produk investasi MTN ini. Perlindungan untuk Investor Pemegang MTN dapat diberlakukan mekanisme preventif guna memitigasi risiko-risiko atas pembelian suatu produk investasi berupa MTN. Mekanisme-mekanisme yang dapat dilakukan adalah pemeringkatan terhadap MTN serta menerapkan prinsip keterbukaan informasi terhadap Emiten. Sebaiknya kedua mekanisme tersebut dapat dijalankan sehingga kepentingan Emiten dapat terlindungi dengan baik.

\section{DAFTAR BACAAN}

\section{Buku}

Alwi, Iskandar Z., Pasar Modal: Teori dan Aplikasi, Yayasan Pancur Siwah, Jakarta, 2003;

Fuady, Munir, Pengantar Hukum Bisnis: Menata Bisnis Modern di Era Global, Citra Aditya Bakti, Bandung, 2008;

Hadjon, Philipus M., Perlindungan Hukum bagi rakyat Indonesia, Bina Ilmu, Jakarta, 1978;

Hernoko, Agus Yudha, Hukum Perjanjian Asas Proporsionalitas dalam Kontrak Komersial, Kencana Prenadamedia Group, Jakarta, 2014;

Isnaeni, Moch, Perjanjian Jual Beli, Revka Petra Media, Jakarta, 2015;

Joni, Emirzon, Hukum Surat Berharga dan Perkembangannya di Indonesia, PT.Prenhallindo, Jakarta, 2001;

Marzuki, Peter Mahmud, Penelitian Hukum (Edisi Revisi, cetakan ke-VIII), Kencana Prenada Media Group, Jakarta, 2013;

Muhammad, Abdulkadir, Hukum Dagang tentang Surat-Surat Berharga, Citra Aditya Bakti, Bandung, 1998;

Nasarudin, Mohammad Irsan, Aspek Hukum Pasar Modal Indonesia, Kencana Prenada Media Group, Jakarta, 2007;

Prodjodikoro Wirjono, Hukum Wesel, cek dan Aksep di Indonesia, Haevarindo, Jakarta, 2011;

Salim H. S., Hukum Kontrak: Teori \& Teknik Penyusunan Kontrak, Sinar Grafika, Jakarta, 2003; 
Setiyadi A., Aspek Hukum Obligasi dan Sukuk, Sinar Grafika, Jakarta, 2009;

Sitorus, Tarmiden, Pasar Obligasi Indonesia: Teori dan Praktik, Cetakan ke-2, Rajagrafindo Persada, Jakarta, 2015;

Soeroso R., Pengantar Ilmu Hukum, Sinar Grafika, Jakarta, 2001;

Sofwan, Sri Soedewi Masjchoen, Hukum Perdata Hukum Perutangan, Fakultas Hukum Universitas Yogyakarta, 1980;

Subekti, Aneka Perjanjian, Citra Aditya Bakti, Bandung, 1995;

Subekti, Hukum Perjanjian, Intermasa, Jakarta, 1992;

Subekti, Pokok-Pokok Hukum Perdata, Intermasa, Jakarta, 1996;

Sunariyah, Pengantar Pengetahuan Pasar Modal Indonesia, Cet. 2, UPP-AMP YKPN, Yogyakarta, 2000;

Suryohadibroto, Imam Prayogo dan Djoko Prakoso, Surat Berharga: Alat Pembayaran dalam Masyarakat Modern, Rineka Cipta, Jakarta, 1991;

Sutedi, Adrian, Obligasi Dalam Perspektif Hukum Indonesia, Cet. I, Citra Aditya Bakti Bandung, 1996;

Wijaya, Gunawan dan Jono, Penerbitan Obligasi dan Peran serta Tanggung Jawab Wali Amanat dalam Pasar Modal, Kencana Prenada Media Group, Jakarta, 2001.

\section{Peraturan Perundang-Undangan}

Burgerlijk Wetboek, Stb.1847-23 (Kitab Undang-Undang Hukum Perdata);

Wetboek van Koophandel voor Indonesie, S. 1847-23 (Kitab Undang-Undang Hukum Dagang);

Undang-Undang Nomor 8 Tahun 1995 tentang Pasar Modal (Lembaran Negara Republik Indonesia Tahun 1995 Nomor 64, Tambahan Lembaran Negara Republik Indonesia Nomor 3608);

Undang-Undang Nomor 10 tahun 1998 tentang Perbankan tentang perubahan atas Undangundang Republik Indonesia Nomor 7 tahun 1992 tentang perbankan (Lembaran Negara Republik Indonesia Tahun 1998 Nomor 182 dan Tambahan Lembaran Negara Republik Indonesia Nomor 3790);

Undang-Undang Nomor 3 Tahun 2004 tentang perubahan atas Undang-Undang Nomor 23 Tahun 1999 tentang Bank Indonesia (Lembaran Negara Republik Indonesia tahun 2004 Nomor 7 dan Tambahan Lembaran Negara Republik Indonesia tahun 1999 Nomor 66); 
Undang-Undang Republik Indonesia Nomor 21 Tahun 2011 tentang Otoritas Jasa keuangan (Lembaran Negara Republik Indonesia Tahun 2011 Nomor 111 dan Tambahan Lembaran Negara Republik Indonesia Nomor 5253);

Peraturan Bank Indonesia Nomor 18/11/PBI/2016 tentang Pasar Uang, (Lembaran Negara Republik Indonesia Tahun 2016 Nomor 148 dan Tambahan Lembaran Negara Republik Indonesia Nomor 5909);

Peraturan Bank Indonesia Nomor 18/12/PBI/2016 tentang Operasi Moneter (Lembaran Negara Republik Indonesia Tahun 2016 Nomor 172 dan Tambahan Lembaran Negara Republik Indonesia Nomor 5919);

Peraturan Bank Indonesia Nomor 10/34/PBI/2008 tentang Transaksi Pembelian Wesel Ekspor Berjangka oleh Bank Indonesia (Lembaran Negara Republik Indonesia Tahun 2008 Nomor 195 dan Tambahan Lembaran Negara Republik Indonesia Nomor 4942);

Peraturan Otoritas Jasa Keuangan Nomor 29/POJK.05/2014 tentang Penyelenggaraan Usaha Perusahaan Pembiayaan (Lembaran Negara Republik Indonesia Tahun 2014 Nomor 364, Tambahan Lembaran Negara Republik Indonesia Nomor);

Peraturan Otoritas Jasa Keuangan Nomor 3/POJK.05/2015 tentang Investasi Dana Pensiun (Lembaran Negara Republik Indonesia Tahun 2015 Nomor 82, Tambahan Lembaran Negara Republik Indonesia Nomor 5692);

Peraturan Otoritas Jasa Keuangan Nomor 23/ POJK.04/2017 tentang Prospectus Awal dan Info Memo (Lembaran Negara Republik Indonesia Tahun 2017 Nomor 123, Tambahan Lembaran Negara Republik Indonesia Nomor 6070);

Surat Keputusan Direksi Bank Indonesia Nomor 28/52/KEP/DIR tanggal 11 Agustus 1995.

Keputusan Ketua Bapepam dan LK Nomor Kep-412/BL/2010 Peraturan Nomor VI.C.4 tentang Ketentuan Umum dan Kontrak Perwaliamanatan Efek Bersifat Utang;

Keputusan Direksi PT Kustodian Sentral Efek Indonesia Nomor: KEP-0013/DIR/KSEI/0612 tentang Perubahan Peraturan Jasa Kustodian Sentral.

\section{$\underline{\text { Website }}$}

https://www.bi.go.id/id/perbankan/lembaga-pemeringkat/Contents/Default.aspx

https://fokus.kontan.co.id/news/ada-apa-di-balik-gagal-bayar-mtn-snp-finance 